\title{
Home Background and Senior Secondary Students' Achievement in Mathematics in Rivers State, Nigeria
}

\author{
Daso Peter Ojimba, Ph.D \\ Senior Lecturer \\ Department of Technical Education \\ Ignatius Ajuru University of Education, Port Harcourt, Rivers State
}

\section{Doi:10.5901/jesr.2013.v3n2p283}

\begin{abstract}
This research study focused on the relationship between home background and students' achievement in mathematics at the senior secondary school level in Rivers State, Nigeria. The ex-post-facto research design was adopted for this study, since already conducted mathematics test scores of the students were retrieved and used for the analysis. Furthermore, data were elicited through the home background and students achievement in mathematics questionnaire (HBSAMQ). A population of 10120 senior secondary II students were involved in the study out of which 4510 were chosen for the sample using the Yarrow Yamen's formula. The data were analyzed using the Z-test statistic, means and simple percentages. The findings were that there is a significant relationship between home support for mathematics, socio-economic status of parents and students achievement in mathematics.
\end{abstract}

Keywords: Home background, socio-economic status, support of education mathematics achievement

\section{Introduction}

The Third International Mathematics and Science Study (TIMSS) represent the most comprehensive international comparism of students' achievement yet conducted (Kiamanesh, 2005). The TIMSS assessment was conducted to study the effects of different factors on students' achievement, including instructional activities, classroom environment, home background and possessions, students' confidence in mathematics and science ability, and students' attitudes towards mathematics.

The preliminary investigations of the TIMSS data in Iran indicated that there is a positive relationship between students' achievement in mathematics and science and home background variable such as parents level of education, number of books at home and possessing dictionary, computer and study desk. However, Iranian students who come from a family with higher level of education of either parents ( $8 \%$ of the students) possess all the three educational aids i.e. dictionary, desk and computer ( $5 \%$ of the students) and have more than 200 books at home (9\% of the students), scored much lower than the international average score (Kiamanesh and Khereih, 2011).

Previous study on TIMSS, 1999 data in Iran, using factor analysis and regression analysis showed that mathematics self-concept and home background were the strongest factors in predicting students' mathematics achievement. These two factors explained 12.5 and 5.4 percent of the variance in Iranian students' mathematics score respectively. The most important factors affecting the Iranian girl students' mathematics achievement were self-concept and home background that accounted for 13.6 and 6.9 parent of the variance in the girls' mathematics score respectively. However, the aforementioned factors explained 12.2 and 4.6 percent of the variance in the Iranian boy students' mathematics score, respectively (Kiamanesh, 2004).

Invariably, a students' home environment can be seen as an agency that aids in the construction of student attitudes and school achievement. Martin (1996) posited that many studies have in fact shown that there is a relationship between family background characteristics and students' achievement. Researchers have suggested that achievement in mathematics and science in secondary school is a function of many interrelated variables such as students' ability, attitudes and perceptions, socio-economic variables, parent and peer 
influences, and school related variables. Many of these variables are home and family-related and thus are difficult to change and are outside the control of educators (Sign, Granille and Dika, 2002).

Arguing further, Beane and Lipka (2003) posited that some of the young peoples' difficulties at school can be due to problems caused by parents. They argued that home is the backbone for children's personality development and influence children directly and indirectly through the kind of relationship the family members have among themselves as well as through helping then to get in contact with society.

In the Nigerian context, Sharma (1997) contended that home environment exerts a significant influence on students' educational aspirations, which in turn influence the school-to-work transition. In other words, when parents have high expectations, youths have high occupational aspirations. Sjogren (2002) emphasized that youths from poorly educated parents are sensitive to economic incentives since they are to a greater extent attracted to occupations with high wage rates and high return in education.

Hence, this study seeks to investigate the extent home background has relationship with students' achievement in mathematics at the senior secondary II level in Rivers State, Nigeria.

\section{The Problem}

An increasing number of students are experiencing mathematics problems. On the international scene, United States of America had recorded dropping percentage in mathematics achievement (Coetzer, 2001). The national pass rate for mathematics in South Africa was 49,5\% in 2004, dropping to 46,3\% in 2005 and to 42,1\% in 2006 (Pretroia News, II July, 2007). In the case of Iranian students, Kiamanesh (2005) found that factors responsible for variance in mathematics included home background of the students (2,5\%). In the Nigerian context, Ojimba (2000) had found that the governments, parents, guardians, teachers and the general public have continued to show concern about the standard of mathematics and the consequent poor performance in mathematics of our primary and secondary school pupils. Corroborating this view, Adegboye (2001) posited that the general poor trend of performance by students in mathematics at the secondary school level is no longer debatable. Though, Adeniye (2003) had associated the poor performance of students in mathematics to poor teaching methods, the literature on home background factors and achievement in mathematics are scanty.

Re-echoing the relevance of the home to science achievement in general, Ahiakwo (2006) harped that home science experience, are useful to formal school science. He stated that if a good teacher should teach a lesson beginning from the known to the unknown, a good starting point is the previous knowledge arising from what the learner knows. A careful perusal of these statements suggest a likely relationship between home background factors and students' achievement in mathematics. The question now comes - to what extent does home background factors relate to students' achievement in mathematics at the senior secondary II level in Rivers State, Nigeria?

\section{Theoretical Background}

Valdez (2006) stated that "there is a huge risk of educators' neglect or overlooks of cultural values and family engagement in the learning process". Many educators focus on effective instruction in the mathematics and science learning without paying much attention to the idea of home support for education. Researchers often argue that learning in the home is crucial in helping all children become and remain motivated learners.

In his views, Schaverien (2001) stated that "the freedom felt in a familiar non-threatening environment of one's home encourages scientific and mathematical exploration that, in a formal school setting may be intimidating". Furthermore, at home, parents engagement in their children's learning strengthens children's capabilities for intellectual growth and allows them to make sense out to everyday activities, thereby deepening their understanding of mathematics, science and technology.

Secada (2001) noted that "children who are deeply involved with their families tend to "persistently ask questions" to continually observe and participate in the mature activities of the communities. They tend to adopt strategies such as looking, reading and manipulating to repeatedly explore exhibits. In other words, do all students encounter a wealth of home practices that contain mathematical content? If the students engage in all of these activities or practices, are they likely to increase students' achievement in mathematics at the secondary school level? 
Supporting the importance of home education for students' achievement in mathematics, Hall (2002) stated that "central to learning at home are partners of learning with understanding". He observed that many approaches parents (especially mothers or caretakers of young children) use to facilitate a child's understanding should be used in classroom based teaching. However, researchers have documented many difficulties experienced by the parents on the education of their children especially in mathematics. McCollum and Russo (2003) outlined the following four concerns:

1. Parents do not necessarily see structured time together as beneficial to their children, nor do they always see the learning value of play.

2. Parents may unwittingly subvert the purpose of the time together by taking over the tasks themselves to make sure that they are done properly.

3. Creating activities that all participants can carry out together is difficult. Older children are often more proficient in English than their parents, which can complicate group dynamics.

4. Many parents look at parent - child time as simply the price they must pay to have access to the adult instruction.

As evident from these concerns, is it not complicated to develop students' achievement in mathematics if home support for education is ignored? What is the situation on the international scene? Let us proceed to examine some studies on home background with special reference to home support for students' achievement in mathematics. Halpern and Myess (2003) found that pre-school experience has a modest but positive influence on initial achievement of primary school in developing countries. The trends in international mathematics and science study (TIMSS) and progress in International Reading Literacy Study (PIRLS) are the largest and most comprehensive international studies that Iran has ever participated in. In these international studies, students' achievement in mathematics, science and reading comprehension have been subjected to comprehensive analysis. In addition, numerous background variables affecting students' achievement have been investigated using background questionnaires.

PISA (2005) carried out an investigation on students' achievement in mathematics. The December 2006 issue of education mathematics reported on the latest results from the programme for international student assessment (PISA) for students' achievement in mathematics. It found out that among the 41 participating countries, students in only two - Hong Kong China and Finland performed better than Canadian students in mathematics. Students in seven other countries performed as well as Canadian students, while students in the remaining countries performed less well. In fact, students in three provinces - Alberta, Quebec and British Columbia ranked among the best in the world.

Drawing from the analysis of PISA (2005) results, two sets of factors affected student achievement in mathematics. The first consists of the role played by student attitudes to and perceptions of mathematics. The second consists of the relationship between parent education and occupation and students' mathematics performance.

Furthermore, socio-economic status (SES) is a term used to summarize a variety of actors including parental education and occupations that influence student performance. Simich-Dudgeon and Weinstern-shor (2004) found that other socio-economic characteristics (e.g. parents' education, income, median age, home ownership, number of children) taken into consideration, students are more likely to succeed academically if their parents actively support their learning. They outlined the socio-economic roles of parents in students' achievement as below:

a) Provide "a home environment that supports children's learning needs

b) Volunteer in schools as aides or in other roles

c) Monitor children's progress and communicate with other personnel

d) Tutor children at home to reinforce work done in school.

In addition, Sticht and Weinstein-shr (2005) found that children's achievement in school was directly correlated with the mother's level of education as mother is usually the first teacher. Furthermore, constructing conversations, talking about books and pictures in those books, telling bedtime stories, reading aloud, and asking questions are important steps towards developing the children's literacy skills. Weinstein-shr (2005) cites research that shows how parent-child interaction affects students learning and how such interaction is especially valuable where literacy in a foreign language is new to both parent(s) and child. Arguably, because the family is a crucial resource for making sense of a new life in a new setting, its basic economic, social and psychological 
needs should be reflected in designing ways to help learners achieve mathematical and scientific proficiency and power.

However, in PISA (2003), SES is measured by an index that includes information describing family structure, parental education and occupation, parental labour market participation, and whether a students' family has specific educational and cultural possessions at home. An earlier analysis of PISA (2000) results, which focused mainly on literacy, found that students from higher socio-economic families tended to show stronger literacy skills. The same result was found in PISA (2002) in which students from families with higher socioeconomic status also tended to perform better in students' achievement in mathematics.

Comparing Canada with other countries, differences in socio-economic status had a smaller impact on students' achievement. Furthermore, differences in socio-economic status among Canadian students also were smaller than in most countries. In the same vein, parental occupation may also influence how students perceive the value of mathematics learning, their beliefs about the usefulness of mathematics and the learning environment at home. Examining this further, if occupation is considered, as an indicator of parental skill use, it appears that students whose parents worked in occupations with greater skill requirements also performed better in mathematics.

Critically examining the PISA (2002) results, students whose parents were in professional or managerial occupations were found to have higher mathematics achievement than others. In other words, students who parents had occupations that specifically required strong mathematical skills - that is, physical mathematical and engineering science professionals tended to have higher mathematical scores than other students. It was also observed that students whose officials executives occupational category that includes legislators, senior officials, executives and managers in fact performed almost one proficiency level lower than students whose parents worked in the mathematics intensive occupational group.

Mburza (2003), said that parents of Nigerian secondary school students being largely illiterates are scarcely capable of reading well informed decisions about the future of their youths. Thus ever-so-often, it is the parents own misconceptions of the nature of work rather than the demand on the employment market that provides many youths with the prime stimulus to select occupation. Earlier, Bojuwoye (2000) affirmed that Nigerian parents (especially the educated ones) are known to be in the habit of dictating career choices to the students. These parents, he stressed, need assistance of a counseling nature in developing appropriate skills in parent-child interaction. Sjogen (2002) found that parental formal education is another factor influencing occupational choice of the student. He harped that youths from poorly education parents are sensitive to economic incentives since they are to a greater extent attracted to occupations with high wage rates and high returns to education. Adesemowo and Adenuga (1998) earlier noted that educated parents were more concerned about their children than the uneducated ones. This might be as a result of their level of education which have exposed them to series of information about life generally.

Echebe (2000) noted that, development of interest in occupation starts from the home. He stressed that the occupation of the individual's parents and other key figures in his/her family influences the occupational choice of such an individual. Smith and Cheung (2004) conducted a study on the Philippines primary school children and found that home support for education from the parents had shaped the school attainment of their children. Several studies have explored the relationship between home background of students and their achievement in mathematics in China, India, Kenya, Nepal, the Philippines and Thailand. Could this be true for Nigeria and RiversState in particular? There is a yawning gap in literature concerning home background and students achievement in mathematics, besides the literature available are scanty hence the need to investigate this relationship and its extent.

\section{The Method}

The ex-post factor research design was adopted for this study because it seeks to investigate an existing phenomenon regarding students' achievement in mathematics. The population of the study consisted of 10,120 senior secondary II students in Rivers State, Nigeria. However, the sample size of 4510 was selected for the study, using the Yarrow Yamen's formula. The research instrument is the home background and students' achievement in mathematics questionnaire (HBSAMQ) divided into five sections. To elicit data from the respondents, the instrument was constructed using the following scale: 
1. Very High Extent (VHE)

$\begin{array}{ll}= & 4 \\ = & 3 \\ = & 2 \\ = & 1\end{array}$

The respondents were free to indicate ( $v$ ) in the column against each of the items as it applied to them (see appendix). A decision cut off point of 2.50 was adopted. Any item or component in which the respondents have a mean score of 2.50 and above was regarded as "a high extent"; while a mean score below 2.50 was regarded as "a low extent".

Descriptive and inferential statistics were adopted for this study. In the descriptive statistics, means $(\bar{X})$, variance $\left(\delta^{2}\right)$ and standard deviations $(\delta)$ were computed and tables constructed. Deductions made from results on these tables formed the answers to the research questions $(1,2)$. To test the hypotheses $(1$ and 2$)$, the $z$-test statistic was applied to compare the means of the various variables and those of achievement in mathematics. The 0.05 level of significance was adopted with the degree of freedom as df $=N_{1}+N_{2}-2$

Table 1: Distribution of Population of 10,120 senior secondary II students in Rivers State, Nigeria.

\begin{tabular}{|c|c|c|c|c|}
\hline $\mathrm{S} / \mathrm{N}$ & Local Govt. Area & $\begin{array}{l}\text { No. of } \\
\text { Schools }\end{array}$ & $\begin{array}{c}\text { Population of students } \\
\text { (SS2) }\end{array}$ & $\begin{array}{c}\text { Sample of } \\
\text { students (SS2) }\end{array}$ \\
\hline 1 & Abua/Odual & 11 & 440 & 209 \\
\hline 2 & Ahoada-East & 12 & 480 & 218 \\
\hline 3 & Ahoada-West & 13 & 520 & 226 \\
\hline 4 & Akuku-Toru & 8 & 320 & 177 \\
\hline 5 & Andoni & 10 & 400 & 200 \\
\hline 6 & Asari-Toru & 8 & 320 & 177 \\
\hline 7 & Bonny & 13 & 520 & 226 \\
\hline 8 & Degema & 12 & 480 & 218 \\
\hline 9 & Eleme & 6 & 240 & 150 \\
\hline 10 & Emohua & 19 & 760 & 262 \\
\hline 11 & Etche & 19 & 760 & 262 \\
\hline 12 & Gokana & 12 & 480 & 218 \\
\hline 13 & Ikwerre & 13 & 520 & 226 \\
\hline 14 & Khana & 22 & 880 & 275 \\
\hline 15 & Obio/Akpor & 16 & 640 & 246 \\
\hline 16 & Ogu/Bolo & 3 & 120 & 92 \\
\hline 17 & Okrika & 6 & 240 & 150 \\
\hline 18 & Omuma & 3 & 120 & 92 \\
\hline 19 & Ogb/Egbema/Ndoni & 15 & 600 & 240 \\
\hline 20 & Opobo/Nkoro & 3 & 120 & 92 \\
\hline 21 & Oyibgo & 4 & 160 & 114 \\
\hline 22 & Port Harcourt & 15 & 600 & 240 \\
\hline \multirow[t]{2}{*}{23} & Tai & 10 & 400 & 200 \\
\hline & Total & 253 & 10,120 & 4,510 \\
\hline
\end{tabular}

\section{Results and Discussion}

\section{Research Question 1}

To what extent does home support for mathematics relate to students' achievement in mathematics? 
Table 2: Analysis of the opinion of students on home support for mathematics and students' achievement in mathematics

\begin{tabular}{|c|c|c|c|c|c|c|c|c|}
\hline $\mathrm{S} / \mathrm{N}$ & Question Items & $\begin{array}{l}\text { VHE } \\
\text { (4) }\end{array}$ & $\begin{array}{l}\text { HE } \\
\text { (3) }\end{array}$ & $\begin{array}{l}\text { LE } \\
\text { (2) }\end{array}$ & $\begin{array}{l}\text { VLE } \\
\text { (1) }\end{array}$ & Total & $\begin{array}{c}\text { Mean } \\
(\bar{X})\end{array}$ & $\begin{array}{c}\text { Percentage } \\
\text { rating (\%) }\end{array}$ \\
\hline 1 & $\begin{array}{l}\text { To what extent would your } \\
\text { father be able to do your } \\
\text { maths homework if you ask } \\
\text { him to help }\end{array}$ & $\begin{array}{c}902 \\
(3608)\end{array}$ & $\begin{array}{c}1015 \\
(3045)\end{array}$ & $\begin{array}{c}1691 \\
(3303)\end{array}$ & $\begin{array}{c}902 \\
(902)\end{array}$ & $\begin{array}{c}4510 \\
(10857)\end{array}$ & 2.43 & 60.25 \\
\hline 2 & $\begin{array}{l}\text { Would your mother be able to } \\
\text { do your mathematics home } \\
\text { work if you ask her help? }\end{array}$ & $\begin{array}{c}789 \\
(3156)\end{array}$ & $\begin{array}{c}902 \\
(2706)\end{array}$ & $\begin{array}{c}1736 \\
(3472)\end{array}$ & $\begin{array}{c}1083 \\
(1083)\end{array}$ & $\begin{array}{c}4510 \\
(10417)\end{array}$ & 2.31 & 57.75 \\
\hline 3 & $\begin{array}{l}\text { To what extent does your } \\
\text { father think that learning } \\
\text { mathematics is very important } \\
\text { for you? }\end{array}$ & $\begin{array}{c}1015 \\
(4060)\end{array}$ & $\begin{array}{c}1398 \\
(4194)\end{array}$ & $\begin{array}{c}1691 \\
(3382)\end{array}$ & $\begin{array}{c}406 \\
(406)\end{array}$ & $\begin{array}{c}4510 \\
(12042)\end{array}$ & 2.67 & 66.75 \\
\hline 4 & $\begin{array}{l}\text { To what extent does your } \\
\text { mother think that learning } \\
\text { mathematics is very important } \\
\text { for you? }\end{array}$ & $\begin{array}{c}992 \\
(3968)\end{array}$ & $\begin{array}{c}755 \\
(3365)\end{array}$ & $\begin{array}{c}1601 \\
(3202)\end{array}$ & $\begin{array}{c}1162 \\
(1162)\end{array}$ & $\begin{array}{c}4510 \\
(10597)\end{array}$ & 2.35 & 58.75 \\
\hline 5 & $\begin{array}{l}\text { To what extent does your } \\
\text { father think mathematics is } \\
\text { fun? }\end{array}$ & $\begin{array}{c}969 \\
(3876)\end{array}$ & $\begin{array}{c}1049 \\
(3147)\end{array}$ & $\begin{array}{l}2400 \\
(4800)\end{array}$ & $\begin{array}{c}92 \\
(92)\end{array}$ & $\begin{array}{c}4510 \\
(11915)\end{array}$ & 2.74 & 68.50 \\
\hline 6 & $\begin{array}{l}\text { To what extent does your } \\
\text { father enjoy doing } \\
\text { mathematics }\end{array}$ & $\begin{array}{c}969 \\
(3876)\end{array}$ & $\begin{array}{c}1094 \\
(3282)\end{array}$ & $\begin{array}{l}1860 \\
(3720)\end{array}$ & $\begin{array}{c}587 \\
(587)\end{array}$ & $\begin{array}{c}4510 \\
(9465)\end{array}$ & 2.54 & 63.56 \\
\hline 7 & $\begin{array}{l}\text { To what extent do your } \\
\text { parents encourage you to } \\
\text { learn mathematics at home? }\end{array}$ & $\begin{array}{c}936 \\
(3744)\end{array}$ & $\begin{array}{c}1038 \\
(3114)\end{array}$ & $\begin{array}{l}1826 \\
(3652)\end{array}$ & $\begin{array}{c}710 \\
(710)\end{array}$ & $\begin{array}{c}4510 \\
(11220\end{array}$ & 2.49 & 62.19 \\
\hline 8 & $\begin{array}{l}\text { To what extent do your } \\
\text { parents want you to do well in } \\
\text { mathematics? }\end{array}$ & $\begin{array}{c}1150 \\
(4600)\end{array}$ & $\begin{array}{c}1465 \\
(4395)\end{array}$ & $\begin{array}{c}1759 \\
(3518)\end{array}$ & $\begin{array}{c}136 \\
(136)\end{array}$ & $\begin{array}{c}4510 \\
(12649)\end{array}$ & 2.81 & 70.13 \\
\hline 9 & $\begin{array}{l}\text { To what extent does your } \\
\text { mother enjoy doing } \\
\text { mathematics? }\end{array}$ & $\begin{array}{c}1071 \\
(4284)\end{array}$ & $\begin{array}{c}1082 \\
(3246)\end{array}$ & $\begin{array}{c}1139 \\
(2278)\end{array}$ & $\begin{array}{c}214 \\
(214)\end{array}$ & $\begin{array}{c}4510 \\
(11014)\end{array}$ & 2.45 & 61.25 \\
\hline 10 & $\begin{array}{l}\text { To what extent do your } \\
\text { parents ensure that you have } \\
\text { enough mathematics books at } \\
\text { home? }\end{array}$ & $\begin{array}{c}766 \\
(3064)\end{array}$ & $\begin{array}{c}936 \\
(2808)\end{array}$ & $\begin{array}{c}2334 \\
(4668)\end{array}$ & $\begin{array}{c}474 \\
(474)\end{array}$ & $\begin{array}{c}4510 \\
(11014)\end{array}$ & 2.44 & 61.00 \\
\hline 11 & $\begin{array}{l}\text { To what extent do your } \\
\text { parents provide you } \\
\text { learning resources } \\
\text { mathematics at home? }\end{array}$ & $\begin{array}{c}1003 \\
(4012)\end{array}$ & $\begin{array}{c}1093 \\
(3279)\end{array}$ & $\begin{array}{c}1669 \\
(3338)\end{array}$ & $\begin{array}{l}754 \\
(745)\end{array}$ & $\begin{array}{c}4510 \\
(11374)\end{array}$ & 2.53 & 63.75 \\
\hline 12 & $\begin{array}{l}\text { To what extent does your } \\
\text { general home environment } \\
\text { support the teaching and } \\
\text { learning of mathematics? }\end{array}$ & $\begin{array}{l}1105 \\
(4420)\end{array}$ & $\begin{array}{c}1353 \\
(4059)\end{array}$ & $\begin{array}{l}1015 \\
(2030)\end{array}$ & $\begin{array}{c}1037 \\
(1037)\end{array}$ & $\begin{array}{c}4510 \\
(11546)\end{array}$ & 2.56 & 64.00 \\
\hline & \multicolumn{6}{|l|}{ Group Mean Rating $(\bar{X})=$} & 2.53 & 63.00 \\
\hline
\end{tabular}

Table 2 revealed that the summary result of the total opinion of students on the relationship between home support for mathematics and mathematics achievement was 2.53 indicating a percentage of 63.00 . However, the decision rule says that the mean of the scale used is 2.50 , therefore any score above 2.5 shows that to "a high extent" home support for mathematics is related to students' achievement in mathematics and any score below 2.50 indicates that to "a low extent" home support for mathematics is related to students' 
achievement in mathematics. Hence home support for mathematics is to "a high extent related to students' achievement in mathematics.

\section{Research Question 2}

To what extent does socio-economic status of parents relate to students' achievement in mathematics?

\begin{tabular}{|c|c|c|c|c|c|c|c|c|}
\hline S/N & Question Items & $\begin{array}{l}\text { VHE } \\
\text { (4) }\end{array}$ & $\begin{array}{l}\text { HE } \\
(3)\end{array}$ & $\begin{array}{l}\text { LE } \\
\text { (2) }\end{array}$ & $\begin{array}{l}\text { VLE } \\
\text { (1) }\end{array}$ & Total & $\begin{array}{l}\text { Mean } \\
(\bar{X})\end{array}$ & $\begin{array}{l}\text { Percentag } \\
\text { e rating } \\
\text { (\%) }\end{array}$ \\
\hline 1 & $\begin{array}{l}\text { To what extent does your father's } \\
\text { position in the office influence your } \\
\text { learning of maths? }\end{array}$ & $\begin{array}{c}451 \\
(1804)\end{array}$ & $\begin{array}{c}564 \\
(1692\end{array}$ & $\begin{array}{c}2593 \\
(1692)\end{array}$ & $\begin{array}{c}902 \\
(902)\end{array}$ & $\begin{array}{c}4510 \\
(9584)\end{array}$ & 2.13 & 53.25 \\
\hline 2 & $\begin{array}{l}\text { To what extent does your living in a } \\
\text { government reservation area make } \\
\text { you achieve better grades in } \\
\text { mathematics? }\end{array}$ & $\begin{array}{c}226 \\
(904)\end{array}$ & $\begin{array}{c}350 \\
(1050)\end{array}$ & $\begin{array}{c}2852 \\
(5784)\end{array}$ & $\begin{array}{c}2852 \\
(5784)\end{array}$ & $\begin{array}{c}4510 \\
(8740)\end{array}$ & 1.94 & 48.44 \\
\hline 3 & $\begin{array}{l}\text { To what extent does the income of } \\
\text { your father influence your } \\
\text { achievement in mathematics? }\end{array}$ & $\begin{array}{c}677 \\
(2708)\end{array}$ & $\begin{array}{c}1398 \\
(4194)\end{array}$ & $\begin{array}{c}1691 \\
(3382)\end{array}$ & $\begin{array}{c}744 \\
(744)\end{array}$ & $\begin{array}{c}4510 \\
(11028)\end{array}$ & 2.45 & 61.25 \\
\hline 4 & $\begin{array}{l}\text { To what extent does the } \\
\text { occupation of your father influence } \\
\text { your achievement in mathematics? }\end{array}$ & $\begin{array}{c}361 \\
(1444)\end{array}$ & $\begin{array}{c}519 \\
(1557)\end{array}$ & $\begin{array}{c}2548 \\
(5096)\end{array}$ & $\begin{array}{c}1082 \\
(1082)\end{array}$ & $\begin{array}{c}4510 \\
(9179)\end{array}$ & 2.04 & 51.00 \\
\hline 5 & $\begin{array}{l}\text { To what extent does the } \\
\text { occupation of your mother } \\
\text { influence your achievement in } \\
\text { mathematics? }\end{array}$ & $\begin{array}{c}316 \\
(1264)\end{array}$ & $\begin{array}{c}451 \\
(1353)\end{array}$ & $\begin{array}{c}2650 \\
(5300)\end{array}$ & $\begin{array}{c}1093 \\
(1093)\end{array}$ & $\begin{array}{c}4510 \\
(9010)\end{array}$ & 1.99 & 49.75 \\
\hline 6 & $\begin{array}{l}\text { To what extent does your fathers' } \\
\text { qualification influence your } \\
\text { achievement in mathematics? }\end{array}$ & $\begin{array}{c}259 \\
(1036)\end{array}$ & $\begin{array}{c}406 \\
(1218)\end{array}$ & $\begin{array}{c}2706 \\
(5412)\end{array}$ & $\begin{array}{c}1139 \\
(1139)\end{array}$ & $\begin{array}{c}4510 \\
(8805)\end{array}$ & 1.95 & 48.75 \\
\hline 7 & $\begin{array}{l}\text { To what extent does your mothers' } \\
\text { qualification influence your } \\
\text { achievement in mathematics? }\end{array}$ & $\begin{array}{c}282 \\
(1128)\end{array}$ & $\begin{array}{c}530 \\
(1590)\end{array}$ & $\begin{array}{c}2402 \\
(4804)\end{array}$ & $\begin{array}{c}1226 \\
(1226)\end{array}$ & $\begin{array}{c}4510 \\
(8818)\end{array}$ & 1.95 & 48.75 \\
\hline 8 & $\begin{array}{l}\text { To what extent does your parents' } \\
\text { ownership of a home influence } \\
\text { your achievement in mathematics? }\end{array}$ & $\begin{array}{c}237 \\
(948)\end{array}$ & $\begin{array}{c}338 \\
(1014)\end{array}$ & $\begin{array}{c}2796 \\
(5592)\end{array}$ & $\begin{array}{c}1139 \\
(1139)\end{array}$ & $\begin{array}{c}4510 \\
(8693)\end{array}$ & 1.92 & 48.00 \\
\hline 9 & $\begin{array}{l}\text { To what extent does the median } \\
\text { age of your parent influence your } \\
\text { achievement in mathematics? }\end{array}$ & $\begin{array}{c}203 \\
(812)\end{array}$ & $\begin{array}{c}361 \\
(1083)\end{array}$ & $\begin{array}{c}2740 \\
(5480)\end{array}$ & $\begin{array}{c}1206 \\
(1206)\end{array}$ & $\begin{array}{c}4510 \\
(8581)\end{array}$ & 1.90 & 47.50 \\
\hline 10 & $\begin{array}{l}\text { To what extent does the number of } \\
\text { children at home influence your } \\
\text { achievement in mathematics? }\end{array}$ & $\begin{array}{c}169 \\
(676)\end{array}$ & $\begin{array}{c}203 \\
(609)\end{array}$ & $\begin{array}{c}2672 \\
(5344)\end{array}$ & $\begin{array}{c}1466 \\
(1466)\end{array}$ & $\begin{array}{c}4510 \\
(8095)\end{array}$ & 1.79 & 44.75 \\
\hline 11 & $\begin{array}{l}\text { To what extent does the culture of } \\
\text { your parents influence your } \\
\text { achievement in mathematics? }\end{array}$ & $\begin{array}{c}710 \\
(2840)\end{array}$ & $\begin{array}{c}857 \\
(2571)\end{array}$ & $\begin{array}{c}2526 \\
(5052)\end{array}$ & $\begin{array}{c}417 \\
(417)\end{array}$ & $\begin{array}{c}4510 \\
(10880)\end{array}$ & 2.41 & 60.25 \\
\hline 12 & $\begin{array}{l}\text { To what extent does your father } \\
\text { driving to school in an official car } \\
\text { influence your achievement in } \\
\text { mathematics? }\end{array}$ & $\begin{array}{c}136 \\
(544)\end{array}$ & $\begin{array}{c}180 \\
(540)\end{array}$ & $\begin{array}{c}2706 \\
(5412)\end{array}$ & $\begin{array}{c}1488 \\
(1488)\end{array}$ & $\begin{array}{c}4510 \\
(7984)\end{array}$ & 1.77 & 44.25 \\
\hline & \multicolumn{6}{|l|}{ Group Mean Rating $(\bar{X})=$} & 2.02 & 50.5 \\
\hline
\end{tabular}

Table 3 revealed that the summary result of the total opinion of students on the relationship between socio-economic status of parents and students achievement in mathematics was 2.02 indicating a percentage of 50.5. However, the decision rule says that the mean of the scale used is 2.50 , therefore, any score above 2.5 
shows that to "a high extent" socio-economic status of parents is related to students' achievement in mathematics. Furthermore, any score below 2.5 indicates that to "a low extent" socio-economic status of parents is related to students' achievement in mathematics. Hence socio-economic status of parents is to "a low extent" related to students' achievement in mathematics.

\section{Hypothesis Testing}

\section{Hypothesis 1}

$\mathrm{Ho}_{1}$ :There is no significant relationship between home support for mathematics and students' achievement in mathematics.

Table 4:Z-ratio test of significant relationship between home support for mathematics and students' achievement in mathematics

\begin{tabular}{|c|c|c|c|c|c|c|c|c|c|}
\hline Variable & $\bar{X}$ & $\mathrm{sd}$ & $\mathrm{N}$ & $d f$ & $P$ & $\begin{array}{l}\text { S. } \\
\text { Error }\end{array}$ & Z-cat & Z-crit & Decision \\
\hline $\begin{array}{l}\text { Home support for } \\
\text { mathematics }\end{array}$ & 63.00 & 3.99 & 4510 & & & 0.059 & & $\begin{array}{l}Z>1.96 \\
\text { or }\end{array}$ & Reject $\mathrm{Ho}_{1}$ \\
\hline $\begin{array}{l}\text { Students' } \\
\text { achievement in } \\
\text { mathematics }\end{array}$ & 54.09 & 14.79 & 4510 & 9018 & 0.05 & 0.228 & 38.16 & $Z<-1.96$ & \\
\hline
\end{tabular}

The result on table 4 showed that the calculated value of $Z$ is 38.16 which is greater than the critical value of 1.96 at the degree of freedom 9,018 at the 0.05 level of significance. Since the calculated Z-value is greater than the critical value, the null hypothesis that there is no significant relationship between home support for mathematics and students' achievement in mathematics is rejected. Hence, there is a significant relationship between home support for mathematics and students' achievement in mathematics (see appendix for detailed calculations).

\section{Hypothesis 2}

$\mathrm{Ho}_{2}$ :There is no significant relationship between socio-economic status of parents and students' achievement in mathematics.

Table 5: Z-ratio test of significant relationship between socio-economic status of parents and students' achievement in mathematics.

\begin{tabular}{|c|c|c|c|c|c|c|c|c|c|}
\hline Variable & $\bar{X}$ & sd & $\mathrm{N}$ & df & $P$ & $\begin{array}{l}\text { S. } \\
\text { Error }\end{array}$ & Z-cat & Z-crit & Decision \\
\hline $\begin{array}{l}\text { Home support for } \\
\text { mathematics }\end{array}$ & 50.5 & 5.94 & 4510 & & & 0.088 & & $\begin{array}{l}Z>1.96 \\
\text { or }\end{array}$ & Reject $\mathrm{Ho}_{2}$ \\
\hline $\begin{array}{l}\text { Students' } \\
\text { achievement in } \\
\text { mathematics }\end{array}$ & 54.09 & 14.79 & 4510 & 9018 & 0.05 & 0.228 & -17.87 & $Z<-1.96$ & \\
\hline
\end{tabular}

The result of table 5 showed that the calculated value of $Z$ is -17.87 which is outside the acceptance region of 1.96 and 1.96 at the degree of freedom, 9018 at the 0.05 level of significance region, we reject the null hypothesis that there is no significant relationship between the socio-economic status of parents and students' achievement in mathematics. Hence, there is a significant relationship between the socio-economic status of parents and students' achievement in mathematics. 


\section{Conclusion}

From the analysis of data and the discussion of findings, the following conclusions were made:

1. There is a significant relationship between home support for mathematics and students' achievement in mathematics at the senior secondary II level in Rivers State, Nigeria.

2. There is a significant relationship between parents' socio-economic status and students' achievement in mathematics at the senior secondary II level in Rivers State, Nigeria

\section{Recommendations}

1. Parents/guardians should create an environment at home that lends support for mathematics learning by providing mathematical kits to enhance students' achievement in mathematics.

2. Since the problem of study was the poor performance of students in mathematics at the senior secondary school II level in RiversState, parents should not blame government, teachers of mathematics and WAEC alone, but look inside at home by helping students provide textbooks, workbooks and ensure home tasks are properly done by the students.

3. Since socio-economic status of parents was significantly related to students' achievement in mathematics, the researcher recommended that parents should actively support the learning of their children in such ways as monitoring children's progress and communicating with school personnel, tutor children at home to reinforce work done in school and acting as volunteer in schools as aides or in other roles.

\section{References}

Adegboye, A.O. (2001). An analysis of common errors committed by secondary school students in mathematics problem - solving UNAD Journal of Education 2(1), 63-68.

Adeniyi, M.R. (2003). Students' home background and achievement in mathematics. Journal of Pedagogy. 2(7), $103-105$

Adesomowo, P.O. and Adenuga, A.R. (1998). Focuses of parental anxiety, attending to the special need for counseling the parents. The counselor. Journal of the counseling association of Nigeria, 1(16), 63-65

Ahiakwo, M.J. (2006). Science, Science Education and Scientific literacy. Inaugural professional lecture. Series No. 17, 4.

Beane, J.A. and Lipka, R.P. (2003). Self Concept, self esteem and the curriculum. New York: Teachers College Press. Berkowitz, L. CBS College Publishing.

Bojuwoye, J.O. (2000). Disciplined behaviour in career decision making: the role of parents. The counselor: Journal of Counselling association of Nigeria. 7(2), 91

Coetzer, M. (2001). Home background and its influence on children learning. Journal of counseling. 14(3), 116-121

Echebe, I.P. (2000). How to choose a career, Port Harcourt: Emhai Printing and publishing company.

Hall, M (2002). Empirical research on mathematics achievement. The role of the family. Journal of Research in Mathematics Education. 3(4), 30-35

Kiamanesh, A.R. and Kheirich, M. (2001). Trends in science educational inputs and outputs in Iran. Findings from Third International Mathematics and Science study and its repeat. Tehran: Institute of Educational Research Publication. 2(8), 52-63

Kiamanesh, A.R. (2004). Factors affecting Iranian students' achievement in mathematics. Paper presented in the first IE international research conference (IRC 2004 conference) Lepksia, Cyprus, 81-84.

Kiamanesh, A.R. (2005). Self concept, home background, motivation attitude, attribution and their effect on Iranian students' science achievement. Tehran. Iran.

Martin, M.O. (1996). Third international mathematics and science study: An overview. In M.O. Martin and D.L. Kelly (Eds), Third international mathematics and science study (TIMSS) Technical report, volume 1: Design and development. Chestnut Hill, MA: Boston College.

Mburza, A (2003). Relationship between parents' education and occupation and occupational choice of senior secondary three students in Borno State, Nigeria. Journal of Educational studies, 9(1), 55-60.

McCollum, R. and Russo, K. (2003). Parents involvement in children's education. Journal of Research in Education, 8(6), 41-48

Myers, R.I. (2003). International Mathematics Report. Findings from IEA's report of the third international mathematics and science study at the eight grade. Chestnut Hill, M.A.: Boston College 
Ojimba, P.D. (2000). Evaluation procedures and achievement in mathematics at the secondary school level. An unpublished M.Ed thesis at Rivers State University of Science and Technology Port Harcourt

PISA (2000). Programme for international student assessment for student achievement in mathematics. Education Matters. Hong Kong, 37.

PISA (2002). Programme for international student assessment for student achievement in mathematics. Education matters. Hong. Kong, 51

PISA (2003). Programme for international student assessment for student achievement in mathematics. Education Maters. Hong Kong, 40

PISA (2005). Programme for international student assessment for student achievement in mathematics. Journal of student engagement in mathematics, 16(9), 15-18.

Secade, R. (2001). Family background and achievement in mathematics. Journal of mathematics Research. 17(6) 4-6

Schavarien, M. (2001). Mathematics research on family background. Journal of Mathematics Teaching. 16(10), 18-20

Sharma, F. (1997). Predicting the adult earning capacity of minors. America. The Economic Ltd.

Sigh, K., Granville, M, and Dika, S. (2002). Mathematics and science achievement, effects of motivation, interest and academic engagement studies in educational evaluation. 28(2), 71-76

Simich-Dudgeon, I. and Weinstein-shr, R. (2004). Home background and achievement in mathematics. Journal of Mathematics Research 18(3), 113-119

Sticht, R.L. and Weinstein-shr, B. (2005). Parental influence on choice of career by learners. Journal of Educational Research 10(15), 32-40

Sjogen, A. 2002). Occupational choice and Incentives: the role of family background. Sweden. The Research Institute

Valdez, G. (2006). Family background and achievement in mathematics. North central Eisenhower Mathematics and science consortium

Weinstein-shr, K. (2005). Parents engagement in their children's education. Journal of mathematics teaching. 13(9), 123.

\section{APPENDIX 1}

\section{Testing Hypothesis I}

Computation of Z-calculated using the group means $\left(\mathrm{U}_{1}\right.$ and $\left.\mathrm{U}_{2}\right)$

Variables: Home support for mathematics and students' achievement in mathematics

$\mathrm{H}_{\mathrm{0}}: \mathrm{U}_{1} \quad \mathrm{U}_{2}$

$\mathrm{H}_{\mathrm{A}}: \mathrm{U}_{1} \quad \neq \quad \mathrm{U}_{2}$

Where:

$\begin{array}{lll}\mathrm{U}_{1} & = & 63.00 \\ \mathrm{U}_{2} & = & 54.09 \\ \mathrm{~N}_{1} & = & 4510 \\ \mathrm{~N}_{2} & = & 4510 \\ \delta_{1}{ }^{2} & = & 3.99^{2} \\ \delta_{2}{ }^{2} & = & 14.79^{2}\end{array}$

But $\mathrm{z}_{\mathrm{u} 1-\mathrm{u} 2}=\frac{U_{1}-U_{2}}{\sqrt{\frac{\delta_{1}^{2}}{N_{1}}+\frac{\delta_{2}^{2}}{N_{2}}}}$

$=\frac{63.00-54.09}{\sqrt{\frac{3.99^{2}}{4510}}+\frac{14.79^{2}}{4510}}$

$=\quad 38.16$ 
$\therefore$ Z-cal $=38.16$

Rejection Region:Two-tailed test, thus: $Z>1.96$ or $Z<-1.96$.

Level of Significance: $\alpha=0.05$

Decision:We reject the null hypothesis. Hence, there is a significant relationship between home support for mathematics and students' achievement in mathematics

\section{APPENDIX 2}

Testing Hypothesis 2

Computation of Z-calculated using the group means $\left(U_{1}\right.$ and $\left.U_{2}\right)$

Variables:Socio-economic status of parents and students' achievement in mathematics

$\begin{array}{cll}\mathrm{H}_{\circ}: \mathrm{U}_{1} & = & \mathrm{U}_{2} \\ \mathrm{H}_{\mathrm{A}}: \mathrm{U}_{1} & \neq & \mathrm{U}_{2} \\ \text { Where: } & & \\ \mathrm{U}_{1} & = & 50.5 \\ \mathrm{U}_{2} & = & 54.09 \\ \mathrm{~N}_{1} & = & 4510 \\ \mathrm{~N}_{2} & = & 4510 \\ \delta_{1}{ }^{2} & = & 5.94^{2} \\ \delta_{2}{ }^{2} & = & 14.79^{2}\end{array}$

But $\mathrm{Z}_{\mathrm{u} 1-\mathrm{u} 2}=\frac{U_{1}-U_{2}}{\sqrt{\frac{\delta_{1}^{2}}{N_{1}}+\frac{\delta_{2}^{2}}{N_{2}}}}$

$$
=\frac{50.5-54.09}{\sqrt{\frac{5.94^{2}}{4510}}+\frac{14.79^{2}}{4510}}
$$

$=\quad 17.87$

$\therefore$ Z-cal $=17.87$

Rejection Region:Two-tailed test, thus: $Z>1.96$ or $Z<-1.96$.

Level of Significance: $\alpha=0.05$

Decision:We reject the null hypothesis. Hence, there is a significant relationship between socio-economic status of parents and students' achievement in mathematics. 


\section{APPENDIX 3}

Computation of mean, variance and standard deviation using students' raw scores in mathematics

\begin{tabular}{|c|c|c|c|c|c|c|}
\hline $\begin{array}{l}\text { Class } \\
\text { Interval }\end{array}$ & $\begin{array}{l}\text { Frequency } \\
\text { (f) }\end{array}$ & $\begin{array}{l}\text { Class } \\
\text { mark } \\
(\bar{x})\end{array}$ & $f x$ & $(x-\bar{x})$ & $(x-\bar{x})^{2}$ & ${ }_{f}(x-\bar{x})^{2}$ \\
\hline $21-30$ & 428 & 25.5 & 10914 & -28.698 & 817.845 & 350037.66 \\
\hline $31-40$ & 508 & 35.5 & 18034 & -18.598 & 345.885 & 175709.58 \\
\hline $41-50$ & 631 & 45.5 & 28710.5 & -8.598 & 73.925 & 46646.675 \\
\hline $51-60$ & 1173 & 55.5 & 65101.5 & 1.402 & 1.965 & 2304.945 \\
\hline $61-70$ & 1285 & 65.5 & 84167.5 & 11.402 & 130.01 & 167062.85 \\
\hline $71-80$ & 440 & 75.5 & 33220.0 & 21.402 & 458.04 & 201537.60 \\
\hline \multirow[t]{2}{*}{$81-90$} & 45 & 85.5 & 3847.5 & 31.402 & 986.08 & 44373.60 \\
\hline & $\begin{array}{l}\sum f \\
4510\end{array}$ & & $\begin{array}{l}\sum f= \\
243,995\end{array}$ & & & $\sum f(x-\bar{x})^{2}=987,672.91$ \\
\hline
\end{tabular}

$$
\begin{aligned}
& \text { Mean } \bar{X}=\frac{\sum f x}{\sum f}=\frac{243,995}{4510}=54.09 \\
& \delta 2=\frac{\sum f(x-\bar{x})^{2}}{\sum f}=\frac{987,672.91}{4510}=218.99 \quad \therefore \sqrt{218.99}=14.79
\end{aligned}
$$

$\therefore \delta=14.79$ 